\title{
Gross Capital Inflows in Indonesia: Exploring Bonanzas and Sudden Stops
}

\author{
Syahid Izzulhaqa, Muhammad Rizal Taufikurahman ${ }^{\text {b }}$, Afaqa Hudayac, \\ Mohammad Reza Hafiz Akbar ${ }^{\mathrm{d}}$
}

\begin{abstract}
This paper examines episodes of capital bonanzas and sudden stops in Indonesia by utilising binary response models and several episode-identification approaches. Our identification suggests that whenever bonanza episodes occurred, capital sudden stop episodes followed in a more extended period. The estimations demonstrate that domestic factors are relatively dominant in determining the capital bonanzas, and the federal funds rate has a more significant impact on inducing the probability of capital sudden stops in Indonesia. We also found that Turkey and South Africa are the most contagious economies for Indonesia. This paper proposes some policy reforms to enhance the stability of capital inflows in Indonesia, including financial regulation and public finance policies such as a reverse Tobin tax and market-driven public debt rules.
\end{abstract}

Keywords: Gross capital inflows; Bonanzas; Sudden stops; Indonesia. JEL Classification: E32, E51, F32

a Diponegoro University, Prof. Soedarto Street, Number 13, Tembalang, Tembalang District, Semarang City, Central Java 50275.Email: izzulhaqsyahid@alumni.undip.ac.id

b Corresponding Author. Trilogy University, Jl. TMP. Kalibata No. 4, Daerah Khusus Ibukota Jakarta 12760, Indonesia; Institute for Development of Economics and Finance (INDEF), Institute for Development of Economics and Finance (INDEF), Pasar Minggu Street KM. 18 East Pejaten, Daerah Khusus Ibukota Jakarta 12510, Indonesia.Email: mrizalt@trilogi.ac.id or rizal@indef.or.id

c Diponegoro University, Prof. Soedarto Street, Number 13, Tembalang, Tembalang District, Semarang City, Central Java 50275.Email: afaqahudaya07@gmail.com

d Institute for Development of Economics and Finance (INDEF), Pasar Minggu Street KM. 18 East Pejaten, Daerah Khusus Ibukota Jakarta 12510, Indonesia.Email: reza.hafiz@indef.or.id 


\section{Introduction}

Stable capital flows are vital to most emerging markets and developing economies (EMDEs). Given the globally integrated and liberalised financial market, capital flow instability would disturb not only exchange rate variability but also macroeconomic and financial system stability (Pagliari \& Hannan, 2017). Obstfeld (2012) has demonstrated that growing international integration is like putting a country's fortune into the hands of others; external accidents can affect the domestic economy dramatically. As such, it is crucial for policymakers to ensure stable capital flows.

In the context of global events, several episodes have documented sharp increases (bonanzas) and decreases (sudden stops) in capital inflows in EMDEs. These include post-global financial crisis (GFC) episodes. After the GFC severely damaged the global economy, the Federal Reserve implemented unprecedented monetary policy (UMP) through largescale asset purchases (LSAPs). This policy created a massive increase in capital inflows, high economic growth, and a financial sector boom in EMDE countries, especially the Fragile Five Economies (F5Es) ${ }^{1}$ (Bhattarai, Chatterjee \& Park, 2018). However, numerous studies have also demonstrated that the United States (US) normalisation policy caused sharp decreases in the capital inflows of EMDEs and F5Es (Basri, 2016, 2017; Bevilaqua \& Nechio, 2016; Bhattarai et al., 2018; Dahlhaus \& Vasishtha, 2014; Hannan, 2015; Lavigne, Sarker \& Vasishtha, 2014).

Compared to the other F5Es countries, the Indonesian economy is relatively more resilient and capable of anticipating the Fed's tapering talks in a somewhat shorter period. We document that the Indonesian economy was merely shocked by the taper tantrum in at least three quarters of 2013 (or seven months), while the other F5E countries, except India, were shocked for a more extended period. Basri (2017) explained that the Indonesian government not only implemented countercyclical monetary and macroprudential policies but also actively restructured the primary balance and recomposed the current account deficit. More specifically, the Minister of Finance restructured the primary balance through an oil subsidy cutoff. This is necessary for the Indonesian economy, as the oil subsidy cutoff influences the current account balance (Basri, 2016). As the outcomes of policy responses, the current account deficit fell from 4.4\% of Gross Domestic Product (GDP) to 2.1\% in the fourth quarter of 2013 (Basri, 2017). 
However, even though the Indonesian economy was relatively more resilient to the taper tantrum, Indonesia's capital inflows are still somewhat volatile (see Figure 1). We calculate that throughout the last 14 years, the Indonesian economy has experienced 11 bonanza episodes and 10 sudden stop episodes, which have typically coincided with either external or domestic events (see Table 1 and Figure 2). For instance, Turkey is thought to be one of the causes of the sudden stop in early 2018, which deteriorated the exchange rate stability of the Indonesian economy. Consistent with this, Saleem and Ahmed (2015) also found that CIVETS (Colombia, Indonesia, Vietnam, Turkey, Egypt, and South Africa) financial markets had significant return and volatility spillovers among each other during this period. Previously, the global commodity price slump from 2014 to 2015 also generated a sharp decrease in Indonesia's gross capital inflows. This phenomenon shows that ensuring stable capital inflows is one of the central issues of the Indonesian economy.

Figure 1: Gross Capital Inflows in Indonesia (millions of USD)

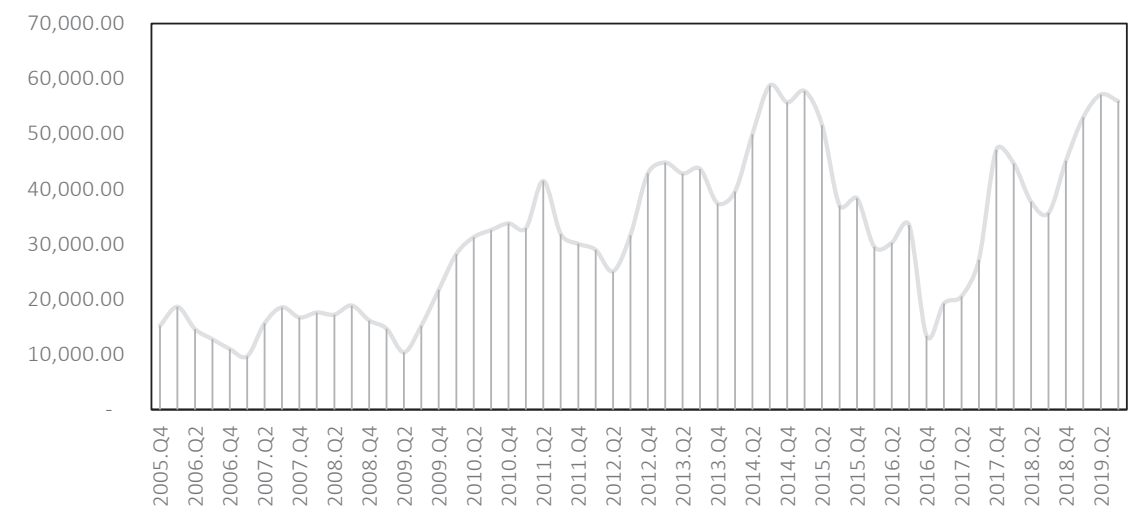

Notes: Data obtained from Economic and Financial Statistics, Bank Indonesia. The figure captures the quarterly year-over-year gross capital inflows from 2005.Q4 to 2019.Q3.

Despite the importance of the issue, little is known about the causes of such episodes in Indonesia. The existing studies have not formally addressed this issue. For instance, Goeltom (2008) analysed only the role of domestic factors in promoting capital inflows in Indonesia. Titiheruw and Itje (2008) focused on economic policies' performance in managing the capital flows in 
Table 1: Description of Bonanza and Sudden Stop Episodes in Indonesia

\begin{tabular}{|c|c|c|c|}
\hline & Number of episodes & Time of episodes & Average duration \\
\hline Bonanzas & 11 episodes & $\begin{array}{c}\text { 2005.Q4; } 2007 . \\
\text { Q2; 2008.Q3; } 2009 . \\
\text { Q2-2009.Q3; } 2011 . \\
\text { Q1; 2012.Q3-2012. } \\
\text { Q4; 2014.Q2-2014. } \\
\text { Q3; 2016.Q2; 2017.Q1; } \\
\text { 2017.Q3-2017.Q4; and } \\
\text { 2018.Q4-2019.Q1. }\end{array}$ & 1.45 quarters \\
\hline $\begin{array}{l}\text { Sudden } \\
\text { Stops }\end{array}$ & 10 episodes & $\begin{array}{c}\text { 2006.Q2-2006. } \\
\text { Q3; 2007.Q4; } 2008 . \\
\text { Q4-2009.Q2; } 2010 . \\
\text { Q3-2010.Q4; } 2011 . \\
\text { Q3; 2013.Q2-2013. } \\
\text { Q4; 2014.Q4-2015.Q3; } \\
\text { 2016.Q4; 2018.Q2; and } \\
\text { 2019.Q3. }\end{array}$ & 1.9 quarters \\
\hline
\end{tabular}

Notes: Authors' calculations. This table describes the bonanzas and sudden stops of capital inflows in Indonesia throughout the last 14 years on a quarterly basis, from 2005 . Q4 to 2019.Q3. The episodes are identified using the Forbes-Warnock criterion.

Figure 2: Bonanza and Sudden Stop Episodes for Indonesia (millions of USD)

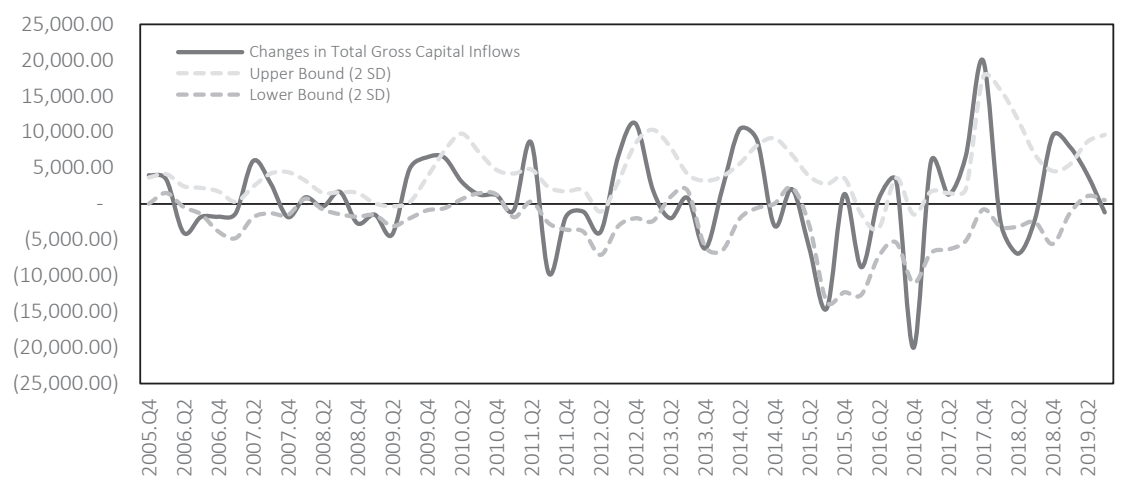

Notes: Data obtained from Economic and Financial Statistics, Bank Indonesia. The figure portrays the bonanza and sudden stop episodes for Indonesia from 2005.Q4 to 2019.Q3. Dashed lines represent the upper and lower bounds, whereas the solid line denotes the quarterly year-over-year changes in gross capital inflows. 
Indonesia, specifically after the Asian financial crisis (AFC). Indawan et al. (2013) examined the determinants of foreign investment behavior, including the risk and returns, both from domestic (pull factor) and global (push factor) circumstances. Finally, Nuryakin, Yuan and Arsana (2016) specifically scrutinised the determinants of portfolio flows in Indonesia.

Given the significance of the issue and the scarcity of the literature, we scrutinise the determinants of bonanzas and sudden stops in Indonesia's gross capital inflows throughout the period of 2005.Q1 to 2019.Q3. This period comprehensively captures several global economic events, including pre-GFC, post-GFC, and the Fed's taper tantrum and policy normalisation (Basri, 2016; Hannan, 2015; Laeven \& Valencia, 2013). This paper also considers the external, domestic, and contagion factors necessary to obtain complete conclusions regarding the forces driving capital bonanzas and sudden stops in Indonesia. For the empirical strategy, we conduct three different binary response models, i.e., logit, probit, and extreme values, and two episode-identification approaches developed by Forbes and Warnock (2012) and Calderón and Kubota (2019). Our rationale for implementing multiple techniques for the econometric method and measurement is that it is essential to ensure that our results are robust.

Our estimations clearly show four crucial findings. First, we find that while domestic and contagion factors are relatively more important than push factors in determining capital bonanzas, the federal funds rate has a greater impact on the probability of capital sudden stops in Indonesia than other statistically significant variables (such as domestic policy rate, changes in international reserves, and current account deficits). Second, we find that the domestic policy rate has an inverse effect; increasing the policy rate increases (reduces) the probability of capital sudden stops (bonanzas). Among other pull factors, the current account deficit is expected to be the main domestic driver of capital sudden stops in Indonesia. Lastly, we found that the contagion effect mainly originates from Turkey and South Africa.

This paper contributes to the literature in several ways. First, it is the first study that explicitly examines the drivers of capital bonanzas and sudden stops in Indonesia. Thus, our main contribution is to provide evidence that domestic, global, and contagion factors are critical drivers of capital inflows' sharp fluctuations in Indonesia. This contributes to the literature on capital flow dynamics in general and the case of Indonesia specifically. Second, this paper describes several policy implications; our 
results indicate that Indonesian policymakers must innovate related policy frameworks, including financial and public sector policies.

The rest of this paper is organised as follows. Section 2 reviews the existing literature. Section 3 elaborates on the empirical strategy relating to the study's econometric method, data, and variables. Section 4 discusses the paper's empirical findings. Section 5 provides both concluding remarks and some policy implications.

\section{Literature Review}

The economic literature includes many studies on capital flow dynamics (see Koepke and Paetzold, 2020). Researchers in this field started by exploring the determinants of capital flows, both addressing the influencing factors and discussing which factors dominate. This led to the debate between push factors, which highlight that external factors are prevalent, and pull factors, which stress the domestic aspects.

The proponents of push factors emphasise the role of external factors such as the interest rate and economic growth of advanced countries, global risk aversion, and global commodity prices as the main drivers of capital flows. For instance, Calvo, Leonardo and Reinhart (1993) investigated the determinants of capital flows in Latin America from 1988 to 1992. They found that push factors, including the recession in the US and lower international interest rates, primarily drive capital flow dynamics in Latin America. Ananchotikul and Zhang (2014) examined the role of external factors in determining portfolio flows into emerging market economies. The authors found that global risk aversion is more dominant than domestic factors such as, financial openness, the exchange rate regime, and macroeconomic fundamentals. More recently, Friedrich and Guérin (2020) studied the role of global variables originating from large economies, finding that such variables are decisive in determining the dynamics of capital flow episodes.

Another strand of the literature emphasises pull factors rather than push factors. Blanchard (2004) analysed the causes of capital outflows (and extreme exchange rate depreciation) in Brazil during the early 2000s. He demonstrated that increases in the policy rate intensify capital outflows due to extensive public debt. In this regard, increases in the policy rate reflect no return but a higher risk, which boosts massive capital outflows. By utilising 
extensive country panel data, Ghosh and Ostry (1993) found that economic fundamentals are the most important drivers of capital flows. Finally, Alberola, Erce and Serena (2016) explored the role of international reserves as a stabiliser of international capital flows, particularly during periods of global financial stress. They found that a larger stock of international reserves is significantly associated with higher capital inflows.

However, some authors have stressed that both pull and push factors are equally important. Hannan (2018) argued that the importance of both external and domestic factors varies over time. Therefore, policies in both source and recipient countries are essential for driving capital flows to EMDEs. Reinhart and Calvo (1996) investigated the determinants of capital inflows in developing countries and found that inflows were primarily attributed to domestic factors, such as sound policies and robust economic performance. However, they suggested that global factors, like cyclical movements in interest rates, were also crucial in determining capital inflow dynamics in developing countries. Fuertes, Phylaktis and Yan (2016) investigated bank credit flows to emerging market economies and found that push and pull factors are equally important for temporary and permanent capital flows.

In addition to the general discussion of the determinants of capital flows, the literature also addresses the more specific question of why countries frequently experience a sharp increase or decrease in capital flows. This issue is essential because such episodes can induce economic vulnerability (Ghosh \& Qureshi, 2016; Reinhart \& Reinhart, 2008). Forbes and Warnock (2012) investigated the determinants of "bonanzas" and "sudden stops" (sharp increases and decreases, respectively, of gross inflows) and "flight" and "retrenchment" (sharp increases and decreases, respectively, of gross outflows) using a large panel dataset. They found that domestic factors are more influential in determining bonanza episodes for emerging economies than for advanced economies. They also demonstrated that financial pull and push factors became more important after 2000. More recently, Calderón and Kubota (2019) investigated the drivers of bonanzas in 74 countries from 1975 through 2014 and made several interesting observations. First, bonanzas in industrial countries or emerging economies are driven by regional contagion. Second, domestic factors such as economic growth and natural resources attract capital inflows into emerging economies. Third, lower global policy uncertainty triggers bonanza episodes, while higher global risk aversion is likely to end capital bonanzas. 


\section{Empirical Strategy}

In this section, we will discuss the empirical features utilised in this paper. We begin by defining bonanzas and sudden stops using quarterly data for Indonesia from 2005.Q4 to 2019.Q3. This period comprehensively captures several global economic events, such as pre-GFC, post-GFC, and the taper tantrum and policy normalisation (Basri, 2016; Hannan, 2015; Laeven \& Valencia, 2013). We then proceed with the definitions of the model variables and the specification of econometric approaches and model estimates. Finally, we address robustness issues to ensure robust and consistent findings.

\subsection{Identifying the episodes of bonanzas and sudden stops}

We identify episodes of bonanzas and sudden stops in Indonesia using total gross capital inflows (a sum of foreign direct investment and portfolio investment). We follow the methodological approach developed by Forbes and Warnock (2012) to identify the episodes of bonanzas and sudden stops. This method has also been utilised frequently in several more recent studies (e.g., Calderón and Kubota 2019). First, we sum the quarterly gross capital inflows (GCI) over the last four quarters, $C_{t}$, as follows:

$$
C_{t}=\sum_{i=0}^{3} G C I_{t-1}, \quad t=1,2, \ldots, N
$$

Then, we specifically utilise the changes in $C_{t}$, denoted $\Delta C_{t}$, as the baseline value to identify the bonanzas and sudden stops of GCI:

$$
\Delta C_{t}=C_{t}-C_{t-4}, \quad t=5,6, \ldots, N
$$

Forbes and Warnock (2012) used one standard deviation above and below the 5 -year rolling means. However, we only use 1 -year rolling means due to data limitations. As such, we estimate the upper and lower bound using +2 (upper-second layer) and -2 standard deviations from the rolling means.

In defining the episodes, we simply follow Forbes and Warnock (2012) and Calderón and Kubota (2019), who described bonanzas (sudden stops) as periods when $\Delta C_{t}$ rises to more (less) than two standard deviations above 
its rolling mean. Accordingly, the end of bonanza (sudden stop) episodes is indicated when $\Delta C_{t}$ falls below (above) the upper (lower) bound of two standard deviations of the rolling mean. Both bonanzas and sudden stops are measured by a dummy variable that takes the value of 1 when the conditions stated above hold and 0 when they do not.

Based on the calculation, we find that the Indonesian economy has experienced longer episodes of sudden stops than bonanzas (see Table 1 and Figure 1). We also observe that when bonanzas occurred, they were frequently followed by longer sudden stops. This supports our hypothesis that ensuring capital inflows' stability is vital for Indonesia's economy.

\subsection{Econometric methodology}

This paper utilises a binary response model, which is a logistic distribution function (logit hereafter) since our dependent variables take the value 1 (bonanzas and sudden stops) and 0 (otherwise). Compared to another binary response model (e.g., linear probability model), this technique distributes the probability within the interval between 0 to 1 . Thus, we can prevent bias from probability linearity, which exceeds the interval limit (Gujarati, 2012; Gujarati \& Porter, 2009). The logit regression is derived by following the logistic probability distribution:

$$
\begin{gathered}
P_{r}=f(z) \\
f(z)=\frac{1}{1+e^{-z}}=\frac{\mathrm{ez}}{1+e^{z}}
\end{gathered}
$$

where $P_{r}$ is the probability of occurrence. The probability of nonoccurrence $\left(1-P_{r}\right)$ is thus expressed as follows:

$$
1-P_{r}=1-\frac{e^{z}}{1-e^{z}}
$$

Therefore, $z$ is obtained from equations (3) and (4) and distributed around 0 to 1 in a sigmoid manner: 


$$
\begin{array}{r}
\frac{P_{r}}{1-P_{r}}=e^{z} \\
\ln \left(\frac{P_{r}}{1-P_{r}}\right)=z
\end{array}
$$

We define $z$ as the function of independent variables, $z=f(X)$. We then obtain an interesting form of regression in time series structure:

$$
z_{t}=\ln \left(\frac{P t}{1-P_{t}}\right)=\beta_{0}+\beta_{1} X_{1 t}+\beta_{2} X_{2 t}+\ldots+\beta_{n} X_{n t}+\mu_{t}
$$

To ensure that the estimation is fit, we use Hosmer-Lemeshow goodness of fit $(\mathrm{H}-\mathrm{L}$ test). This test states that if the null hypothesis is not rejected, the estimation could precisely predict the observation value. In other words, our model is suitable for the observation data. This test uses a chi-squared $\left(\chi^{2}\right)$ probability distribution to test the hypothesis (Gujarati \& Porter, 2009).

\subsection{Specifying model estimates}

To accommodate our research objectives, we utilise several variables categorised into three groups of determinants: push factors, pull factors, and contagion variables. These groups of variables are frequently used in the related literature to analyse the determinants of capital surges (or bonanzas), sudden stops, retrenchments, and in-flight episodes (e.g., Cowan et al., 2008; Ghosh et al., 2014; Calderón \& Kubota, 2019; Forbes \& Warnock, 2012; among others). In addition, our variables follow Hannan's (2018) study that summarises the determinants of capital flows.

Push factors. Push factors are defined as "gatekeepers" that determine the timing and magnitude of capital supplies to developing countries (Ghosh et al., 2014). This group of determinants includes five variables: the growth of the US economy $\left(y_{t}^{*}\right)$; the federal funds rate $\left(i_{t}^{*}\right)$; the US yield spread $\left(\gamma_{t}\right)$ as a foreign recession indicator; the volatility (VIX) index $\left(\delta_{t}\right)$ as a measure of global risk aversion; and WTI $\left(\rho_{t}\right)$ as an indicator of global commodity prices.

Pull factors. Variables included in this group of determinants comprise domestic factors that could attract foreign investors (Calderón \& Kubota, 
2019). In the models, this group of variables contains four domestic variables: the growth of the Indonesian economy $\left(y_{t}\right)$ as domestic economic performance; the domestic policy rate $\left(i_{t}\right)$; changes in international reserves $\left(\Delta i r_{t}\right)$ as the domestic policy indicator; and current account deficit $\left(\vartheta_{t}\right)$ representing domestic structural factors.

Contagion effect. We use episodes of bonanzas and sudden stops in countries that are financially connected to Indonesia to measure the contagion effect. When the financially connected countries experienced bonanzas or sudden stops at the same time as Indonesia, it could indicate that Indonesia's episodes contagiously originated from these countries (or vice versa). We choose four financially connected CIVTS countries (i.e., Colombia, Indonesia, Vietnam, Turkey, and South Africa), as these countries' financial risks are highly linked through portfolio inter-market linkage (Saleem \& Ahmed, 2015).

Our model estimate specification, which aims to analyse the bonanza episodes, is expressed by the following equations:

$$
\begin{aligned}
Y_{t}=\ln \left(\frac{P t}{1-P_{t}}\right)= & \alpha+\varphi \boldsymbol{P u s h}_{i t-\boldsymbol{k}}+\tau \boldsymbol{P u l l}_{\boldsymbol{i t}-\boldsymbol{k}}+\omega \boldsymbol{C S}_{\boldsymbol{i t}}+\varepsilon_{t} \\
& \left.P_{t} \text { Bonanzas }_{t}=1\right)
\end{aligned}
$$

where $C S_{t}$ is a vector of contagion variables that includes bonanza episodes from Colombia, Vietnam, Turkey, and South Africa in the same quarter; $k$ is the length of lag; Push $h_{t-k}=\left\{y_{t-k}^{*}, i_{t-k}^{*}, \gamma_{t-k}^{*}, \delta_{t-k}^{*}, \rho_{t-k}^{*}\right\} ; P u l l_{t-k}$ $=\left\{y_{t-k}, i_{t-k}, \Delta i r_{t-k}, \vartheta_{t-k}\right\}$; and $C S_{t}=\left\{C S_{t}^{C O L}, C S_{t}^{V I E}, C S_{t}^{T R}, C S_{t}^{S A}\right\}$.

In the second model estimate, which aims to investigate the sudden stop episodes, we identify the empirical specification as follows:

$$
\begin{aligned}
X_{t}=\ln \left(\frac{P t}{1-P_{t}}\right)= & \alpha+\varphi \boldsymbol{P u s h}_{\boldsymbol{i t}-\boldsymbol{k}}+\tau \boldsymbol{P u l l}_{\boldsymbol{i t}-\boldsymbol{k}}+\omega \boldsymbol{C S S}_{\boldsymbol{i t}}+\varepsilon_{t} \\
& P_{t}\left(\text { SuddenStops }_{t}=1\right)
\end{aligned}
$$

where $C S S_{i t}$ is a vector of a contagion effect in terms of sudden stop episodes from Colombia $\left(C S S_{t}^{C O L}\right)$, Vietnam $\left(C S S_{t}^{V I E}\right)$, Turkey $\left(C S S_{t}^{T R}\right)$, and South Africa $\left(\operatorname{CSS}_{t}^{S A}\right)$. 
Furthermore, we address two other methodological concerns in our estimations. First, as we use lagged independent variables, the length of lags will be decided by the smallest value of the Akaike information criterion (AIC), Schwartz criterion (SC), and Hannan-Quinn criterion (HQC) that explains the best specification for the models (see Appendices A and B for the results). Second, we standardise the non-dummy variables using $\breve{x}_{i}=\left(\frac{x_{i}-\bar{x}}{\sigma_{i}^{2}}\right)$ so that the data will be normalised in the same unit of account; thus, we can compare the estimated coefficients.

\subsection{Addressing robustness checks}

We perform several estimations to check the robustness of the results. We identify the episodes using an alternative approach provided by Cowan et al. (CDMN, 2008), which normalises the magnitude of quarterly year-overyear changes in capital inflows as the percentage of GDP. Interestingly, we find that the identified episodes are approximately the same as the Forbes and Warnock (FW, 2012) approach. Moreover, we also utilise other binary response models: probit and extreme values (EV). Our rationale for using several econometric techniques is twofold. First, it ensures the consistency of our results. Second, compared to probit and logit, EV uses the probabilities of the complementary log-log ( $\log \log )$, which is capable of handling the skewed probability distribution function. The EV technique is also frequently utilised in related literature, such as Forbes and Warnock (2012) and Calderón and Kubota (2019).

\section{Results and Discussion}

We begin by exploring the role of global (push) factors and capital bonanzas in Indonesia (see Table 2). The estimation shows that the push factors are relatively weak in explaining the bonanza episodes in Indonesia. First, we document that the global commodity price positively affects the probability occurrence of capital bonanza episodes in Indonesia. However, although it consistently has a positive coefficient throughout the estimations, it is only statistically significant in two estimations out of six. We thus consider that the empirical relationship with global commodity prices is relatively weak. We also found weak evidence explaining capital bonanzas for the 
Table 2: Bonanzas in Gross Capital Inflows

\begin{tabular}{|c|c|c|c|c|c|c|}
\hline & \multicolumn{3}{|c|}{ FW Criterion } & \multicolumn{3}{|c|}{ CDMN Criterion } \\
\hline & [1] & [2] & [3] & [4] & [5] & [6] \\
\hline \multicolumn{7}{|l|}{ Push Factors } \\
\hline US growth & $\begin{array}{l}-1.030294 \\
(0.631734)\end{array}$ & $\begin{array}{l}-0.607826 \\
(0.371491)\end{array}$ & $\begin{array}{l}-0.608834 \\
(0.455960)\end{array}$ & $\begin{array}{l}-0.588477 \\
(0.604565)\end{array}$ & $\begin{array}{l}-0.364750 \\
(0.361903)\end{array}$ & $\begin{array}{l}-0.331000 \\
(0.447972)\end{array}$ \\
\hline Federal funds rate & $\begin{array}{c}-0.732063 \\
0.982036\end{array}$ & $\begin{array}{l}-0.413018 \\
(0.569274)\end{array}$ & $\begin{array}{l}-0.265082 \\
(0.671342)\end{array}$ & $\begin{array}{l}-0.037864 \\
(1.134786)\end{array}$ & $\begin{array}{l}-0.000691 \\
(0.632307)\end{array}$ & $\begin{array}{c}0.082789 \\
(0.658999)\end{array}$ \\
\hline US yield spread & $\begin{array}{l}-1.752632 * \\
(1.005890)\end{array}$ & $\begin{array}{l}-0.967747 * \\
(0.565857)\end{array}$ & $\begin{array}{l}-0.767652 \\
(0.633130)\end{array}$ & $\begin{array}{l}-0.666406 \\
(1.035484)\end{array}$ & $\begin{array}{l}-0.353537 \\
(0.584492)\end{array}$ & $\begin{array}{l}-0.239810 \\
(0.620869)\end{array}$ \\
\hline Volatility index (VIX) & $\begin{array}{l}-0.388501 \\
(0.565858)\end{array}$ & $\begin{array}{l}-0.239082 \\
(0.324102)\end{array}$ & $\begin{array}{l}-0.352019 \\
(0.396550)\end{array}$ & $\begin{array}{l}-0.297019 \\
(0.532023)\end{array}$ & $\begin{array}{l}-0.176962 \\
(0.311930)\end{array}$ & $\begin{array}{l}-0.277805 \\
(0.378674)\end{array}$ \\
\hline $\begin{array}{l}\text { Global commodity } \\
\text { prices (WTI Index) }\end{array}$ & $\begin{array}{l}1.603848 * * \\
(0.774809)\end{array}$ & $\begin{array}{l}0.898971 * * \\
(0.438663)\end{array}$ & $\begin{array}{l}0.771824 * \\
(0.447875)\end{array}$ & $\begin{array}{c}0.898143 \\
(0.727732)\end{array}$ & $\begin{array}{c}0.489821 \\
(0.416201)\end{array}$ & $\begin{array}{c}0.387247 \\
(0.441691)\end{array}$ \\
\hline \multicolumn{7}{|l|}{ Pull Factors } \\
\hline Indonesian growth & $\begin{array}{l}-0.287766 \\
(0.596287)\end{array}$ & $\begin{array}{l}-0.146145 \\
(0.341061)\end{array}$ & $\begin{array}{l}-0.144090 \\
(0.359280)\end{array}$ & $\begin{array}{l}-0.423621 \\
(0.595255)\end{array}$ & $\begin{array}{l}-0.221622 \\
(0.335352)\end{array}$ & $\begin{array}{l}-0.194014 \\
(0.345381)\end{array}$ \\
\hline Domestic policy rate & $\begin{array}{l}-1.314003 * \\
(0.685353)\end{array}$ & $\begin{array}{c}-0.747288^{* *} \\
(0.357687)\end{array}$ & $\begin{array}{c}-0.935035^{* *} \\
(0.476601)\end{array}$ & $\begin{array}{c}-1.391191 * * \\
(0.679860)\end{array}$ & $\begin{array}{c}-0.787454^{* *} \\
(0.355440)\end{array}$ & $\begin{array}{l}-0.941359^{*} \\
(0.484577)\end{array}$ \\
\hline $\begin{array}{l}\text { Changes in } \\
\text { international reserves }\end{array}$ & $\begin{array}{c}0.336364 * * \\
(0.155647)\end{array}$ & $\begin{array}{l}0.193411 * * \\
(0.089630)\end{array}$ & $\begin{array}{c}0.193127 * * \\
(0.090968)\end{array}$ & $\begin{array}{l}0.285086^{*} \\
(0.164302)\end{array}$ & $\begin{array}{l}0.164089^{*} \\
(0.090168)\end{array}$ & $\begin{array}{l}0.163264 * \\
(0.085685)\end{array}$ \\
\hline Current account deficit & $\begin{array}{c}0.037122 \\
(0.302488)\end{array}$ & $\begin{array}{c}0.020961 \\
(0.165955)\end{array}$ & $\begin{array}{c}0.011101 \\
(0.179321)\end{array}$ & $\begin{array}{c}0.090640 \\
(0.295428)\end{array}$ & $\begin{array}{c}0.054527 \\
(0.165945)\end{array}$ & $\begin{array}{c}0.034664 \\
(0.175221)\end{array}$ \\
\hline \multicolumn{7}{|l|}{ Contagion Effect } \\
\hline From Colombia & $\begin{array}{c}0.368225 \\
(1.030209)\end{array}$ & $\begin{array}{c}0.189709 \\
(0.563645)\end{array}$ & $\begin{array}{l}-0.134875 \\
(0.684196)\end{array}$ & $\begin{array}{c}0.662145 \\
(1.065014)\end{array}$ & $\begin{array}{c}0.339944 \\
(0.574176)\end{array}$ & $\begin{array}{c}0.026407 \\
(0.626352)\end{array}$ \\
\hline From South Africa & $\begin{array}{c}0.922799 \\
(0.963364)\end{array}$ & $\begin{array}{c}0.414393 \\
(0.519912)\end{array}$ & $\begin{array}{c}0.429168 \\
(0.552917)\end{array}$ & $\begin{array}{c}0.980878 \\
(1.033451)\end{array}$ & $\begin{array}{c}0.475955 \\
(0.547108)\end{array}$ & $\begin{array}{c}0.502666 \\
(0.573856)\end{array}$ \\
\hline From Turkey & $\begin{array}{l}3.130041^{* * *} \\
(1.158738)\end{array}$ & $\begin{array}{c}1.720780^{* * *} \\
(0.547420)\end{array}$ & $\begin{array}{c}1.868029 * * * \\
(0.688556)\end{array}$ & $\begin{array}{l}2.639895^{* *} \\
(1.103067)\end{array}$ & $\begin{array}{c}1.430930 * * * \\
(0.553197)\end{array}$ & $\begin{array}{l}1.554233^{* *} \\
(0.668220)\end{array}$ \\
\hline From Vietnam & $\begin{array}{c}1.371229 \\
(1.090285)\end{array}$ & $\begin{array}{c}0.715472 \\
(0.583535)\end{array}$ & $\begin{array}{c}0.402393 \\
(0.530110)\end{array}$ & $\begin{array}{c}1.450532 \\
(1.131190)\end{array}$ & $\begin{array}{c}0.722974 \\
(0.586866)\end{array}$ & $\begin{array}{c}0.428388 \\
(0.536322)\end{array}$ \\
\hline McFadden R-squared & 0.424614 & 0.418472 & 0.419151 & 0.385944 & 0.380150 & 0.384852 \\
\hline LR statistic & $27.36838 * *$ & $26.97255^{* *}$ & $27.01629 * *$ & $24.08294 * *$ & $23.72138 * *$ & $24.01480 * *$ \\
\hline $\begin{array}{l}\mathrm{H}-\mathrm{L} \text { probability (chi- } \\
\text { squared value) }\end{array}$ & 0.7135 & 0.6774 & 0.2312 & $0.0761 *$ & $0.0846^{*}$ & 0.3996 \\
\hline Observations & 55 & 55 & 55 & 55 & 55 & 55 \\
\hline Estimation method & Logit & Probit & $\begin{array}{l}\text { Extreme } \\
\text { values }\end{array}$ & Logit & Probit & $\begin{array}{l}\text { Extreme } \\
\text { values }\end{array}$ \\
\hline
\end{tabular}

Notes: Authors' calculations. This table reports the estimation results for the bonanza episodes. The results consist of six estimations using various econometric approaches (i.e., logit regression, probability unit, and extreme values) and episode-identification approaches (Forbes-Warnock criterion and Cowan et al. criterion). Independent variables are expressed in one quarterly lagged value. The asterisk denotes statistical significance $*, * *$, and $* * *$ at $10 \%, 5 \%$, and $1 \%$, respectively. Numbers in parentheses represent the Huber-White standard error. 
other variables in this group of determinants, although the coefficients are theoretically accurate.

For the determinant group of pull factors, we found that the policy rate has a dominant role in explaining capital bonanza episodes in Indonesia. Interestingly, we found that a higher policy rate implies a lower probability of capital bonanzas in Indonesia. This, of course, contrasts with conventional wisdom, which states that higher interest rates induce capital inflows as they are more attractive for foreign investors. However, several studies have demonstrated that higher interest rates also imply a higher risk of insolvency due to broader primary balance deficits and higher external debt; higher rates can thus deter capital inflows, especially in emerging economies (e.g., Blanchard, 2004). Other pull determinants appear to be relatively weak in explaining capital bonanzas.

For the contagion factors, we found that Turkey's capital bonanzas have an essential role in explaining the capital bonanzas in Indonesia compared to other CIVTS countries. When the Turkish economy experiences bonanzas, it increases the probability of bonanzas in Indonesia. This is logical since Indonesia and Turkey are considered growing hosts of foreign investors and have high inter-market linkage (Saleem \& Ahmed, 2015). This finding is also robustly consistent throughout the estimation approaches.

Before addressing other aspects of our research question, we note that the identification of sudden stop episodes using both the FW and CDMN criteria produces precisely the same patterns. This indicates that the identifications are robust and consistent for different identification approaches. On the other hand, it limits this model estimate to only three estimations.

For the push factors group, we found that the federal funds rate (FFR) has a significant role in creating sudden stops in Indonesia. Our estimation shows that increases in FFR remarkably increase the likelihood of sudden stops in Indonesia. This finding confirms several studies, specifically in revealing the significant effect of US liftoff episodes during monetary policy normalisation. Ahmed (2015) has illustrated that increases in FFR during the liftoff episodes would heavily deteriorate the capital flows to EMDEs, including Indonesia, for two critical reasons: foreign investors' consideration of risk and dollardominated or foreign-currency-dominated external debt in EMDEs.

Our findings show that in the pull factors group, policy rate, changes in international reserves, and current account deficit substantially affect the probability of sudden stop episodes in Indonesia. First, we address the role 
Table 3: Sudden Stops in Gross Capital Inflows

\begin{tabular}{|c|c|c|c|}
\hline & \multicolumn{3}{|c|}{ FW and CDMN Criterion } \\
\hline & {$[1]$} & [2] & {$[3]$} \\
\hline \multicolumn{4}{|l|}{ Push Factors } \\
\hline US growth & $\begin{array}{l}-0.659917 \\
(0.933535)\end{array}$ & $\begin{array}{c}-0.386982 \\
(0.486771)\end{array}$ & $\begin{array}{l}-0.434582 \\
(0.667910)\end{array}$ \\
\hline Federal funds rate & $\begin{array}{l}2.684738^{*} \\
(1.577632)\end{array}$ & $\begin{array}{l}1.664583 * * \\
(0.821417)\end{array}$ & $\begin{array}{c}2.095636^{* *} \\
(0.992106)\end{array}$ \\
\hline US yield spread & $\begin{array}{c}1.956513 \\
(1.469228)\end{array}$ & $\begin{array}{c}1.221961 \\
(0.757367)\end{array}$ & $\begin{array}{c}1.632670 \\
(1.036962)\end{array}$ \\
\hline Volatility index (VIX) & $\begin{array}{c}0.576135 \\
(0.669445)\end{array}$ & $\begin{array}{c}0.356094 \\
(0.382366)\end{array}$ & $\begin{array}{c}0.382336 \\
(0.572035)\end{array}$ \\
\hline Global commodity prices (WTI Index) & $\begin{array}{l}-0.277052 \\
(0.884922)\end{array}$ & $\begin{array}{l}-0.174732 \\
(0.457995)\end{array}$ & $\begin{array}{l}-0.220667 \\
(0.404586)\end{array}$ \\
\hline \multicolumn{4}{|l|}{ Pull Factors } \\
\hline Indonesian growth & $\begin{array}{l}-0.089226 \\
(0.820499)\end{array}$ & $\begin{array}{l}-0.058065 \\
(0.438960)\end{array}$ & $\begin{array}{l}-0.110177 \\
(0.587191)\end{array}$ \\
\hline Domestic policy rate & $\begin{array}{l}1.448431^{*} \\
(0.764695)\end{array}$ & $\begin{array}{c}0.862142 * * \\
(0.370961)\end{array}$ & $\begin{array}{l}1.010431 * * \\
(0.406865)\end{array}$ \\
\hline Changes in international reserves & $\begin{array}{c}0.533184 * * * \\
(0.204372)\end{array}$ & $\begin{array}{c}0.318848 * * * \\
(0.114984)\end{array}$ & $\begin{array}{c}0.338084 * * \\
(0.151927)\end{array}$ \\
\hline Current account deficit & $\begin{array}{c}1.257787 * * * \\
(0.386039)\end{array}$ & $\begin{array}{c}0.754018 * * * \\
(0.203302)\end{array}$ & $\begin{array}{c}0.884740 * * * \\
(0.284650)\end{array}$ \\
\hline \multicolumn{4}{|l|}{ Contagion Effect } \\
\hline From Colombia & $\begin{array}{c}1.170701 \\
(1.134186)\end{array}$ & $\begin{array}{c}0.666648 \\
(0.588333)\end{array}$ & $\begin{array}{l}0.583466 \\
0.607575\end{array}$ \\
\hline From South Africa & $\begin{array}{c}3.378922 * * * \\
(0.998125)\end{array}$ & $\begin{array}{c}2.033462 * * * \\
(0.540984)\end{array}$ & $\begin{array}{c}2.221028 * * * \\
0.721375\end{array}$ \\
\hline From Turkey & $\begin{array}{c}2.740214 * * * \\
(1.051831)\end{array}$ & $\begin{array}{c}1.611927 * * * \\
(0.548533)\end{array}$ & $\begin{array}{c}1.772235^{* *} \\
0.800175\end{array}$ \\
\hline From Vietnam & $\begin{array}{c}1.278043 \\
(1.186224)\end{array}$ & $\begin{array}{c}0.696848 \\
(0.576692)\end{array}$ & $\begin{array}{l}0.827479 \\
0.689034\end{array}$ \\
\hline McFadden R-squared & 0.425586 & 0.433623 & 0.441801 \\
\hline LR statistic & $28.30502 * * *$ & $28.83955^{* * *}$ & $29.38346^{* * *}$ \\
\hline $\mathrm{H}-\mathrm{L}$ probability (chi-squared value) & 0.4971 & 0.5807 & 0.7684 \\
\hline Observations & 54 & 54 & 54 \\
\hline Estimation method & Logit & Probit & Extreme values \\
\hline
\end{tabular}

Notes: Authors' calculations. This table reports the estimation results for the sudden stop episodes. The results consist of three estimations using various econometric approaches (i.e., logit regression, probability unit, and extreme values) and episode-identification approaches (Forbes-Warnock criterion and Cowan et al. criterion). The FW and CDMN criteria generate the same periods of sudden stops. Independent variables are expressed in three quarterly lagged values. The asterisk denotes statistical significance *,**, and *** at $10 \%, 5 \%$, and $1 \%$, respectively. Numbers in parentheses represent the Huber-White standard error. 
of the policy rate. Higher policy rates imply a higher probability of capital sudden stops. This finding is consistent with the previous estimations. However, it also suggests the asymmetric and countervailing effect of the policy rate in increasing (reducing) the probability of capital bonanzas (sudden stops). Although a higher policy rate implies a lower probability of capital bonanzas, it would increase the likelihood of sudden stops to a greater extent. This indicates two competing effects that, on the one hand, attract capital flows by increasing returns and, on the other hand, deter capital flows by increasing risk. We argue that such effects occur in different periods. A higher interest rate attracts more capital inflows when the domestic solvency risk, such as the level of public debt, is relatively low, while a higher interest rate triggers sudden stop episodes when domestic solvency risk is particularly high (Blanchard, 2004).

We found that foreign exchange intervention (FXI) decreases the probability of capital sudden stops. This indicates that FXI in Indonesia is relatively effective in preventing sudden stop episodes. The transmission is simple: Benes et al. (2015) have demonstrated that when the economy is shocked by international financial conditions (i.e., increases in global interest rates), FXI stabilise the financial system, establishing safer exchange rate risk and lower risk premia. Therefore, the risk premia would offset the effect of the interest rate spread, and both the exchange rate and capital inflows would remain unchanged.

Among other pull factors, our results demonstrate that the current account deficit plays a dominant role in explaining sudden stops in Indonesia; the broader deficits of the current account, the higher the probability of capital sudden stops. This finding supports much of the related literature, which emphasises the role of the current account deficit in determining the capital flows, especially in EMDEs and Indonesia. Obstfeld (2012) has illustrated that, with the investment, the role of the current account is to allow investors to maintain globally diversified portfolios of equity claims through purchases of newly issued shares in the profits of capital. In the case of Indonesia, and particularly during the taper tantrum, Basri $(2016,2017)$ explained that besides implementing countercyclical monetary and macroprudential policies, restructuring the current account deficit was effective to mitigate sudden stops.

For the contagion factors, we found that the Turkish and South African economies have a contagiously significant effect on sudden stop episodes 
in Indonesia. Specifically, when those countries are experiencing a capital sudden stop, it induces a higher probability of capital sudden stops in Indonesia. Interestingly, Turkey and South Africa were within the same groups as Indonesia: the Fragile Five Economies during the taper tantrum and CIVETS countries. This finding suggests that the Indonesian economy should be understood in the context of those countries.

Furthermore, our model estimates also suggest a good specification. The Hosmer-Lemeshow (H-L) chi-squared probability of all model estimates and estimations is above $5 \%$, indicating that our specification fits the observation. The likelihood ratio (LR) statistics reveal that push, pull, and contagion factors simultaneously affect capital bonanzas and sudden stops in Indonesia. Finally, the McFadden R-squared also shows that the determinant factors in each estimation can explain the episodes around 38\% to $44 \%$.

\section{Conclusion and Policy Implications}

This paper sheds light on the role of global, domestic, and contagion factors in determining capital bonanzas and sudden stops in Indonesia from 2005.Q4 to 2019.Q3. By utilising three different forms of binary response model (i.e., logit, probit, and extreme values) and two episode-identification approaches, our estimations reveal several crucial points comprising monetary factors, current account deficit conditions, and contagion drivers.

First, we find that although domestic and contagion factors are relatively more important in determining capital bonanzas, FFR has a greater impact on the probability of capital sudden stops in Indonesia compared to other statistically significant variables; these include domestic policy rate, changes in international reserves, and current account deficits. Interestingly, we also found that the domestic policy rate has a reverse effect. Increases in the policy rate increase (reduce) the probability of capital sudden stops (bonanzas). These findings suggest that something has gone wrong in Indonesia's domestic economy, perhaps triggered by the structure of primary balance and external debt. As portrayed in Figure 3, the Indonesian economy is characterised by a growing government budget deficit, increasing external debt, and high foreign currency domination in external debt. These conditions imply that a higher risk of debt insolvency would follow a higher interest rate; thus, the capital flows from home countries would go to a safer place. 
Figure 3: Cyclicality Behaviour of Fiscal Policy in Indonesia

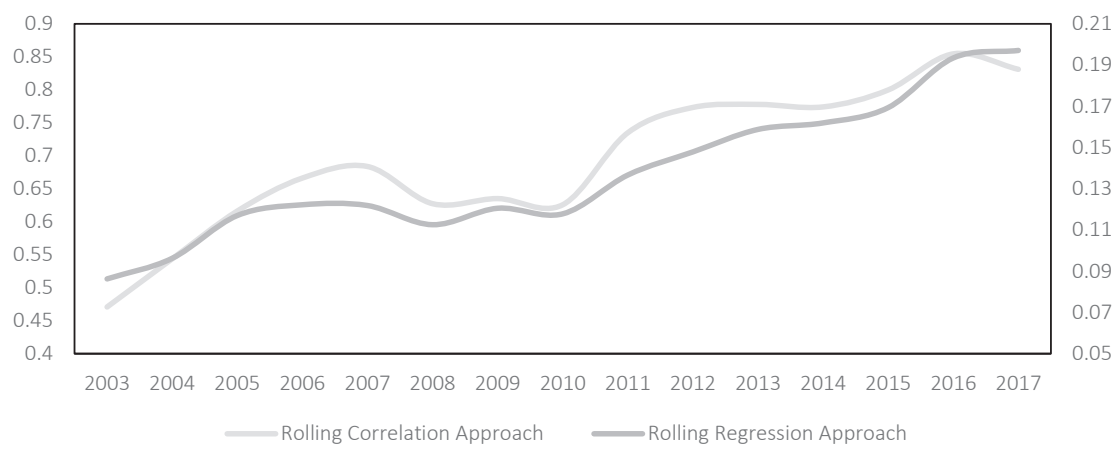

Notes: Authors' calculations. The figure portrays the cyclical behaviour of fiscal policy in Indonesia. A positive (negative) value represents a procyclical (countercyclical) fiscal policy. The represented values are obtained from a rolling correlation approach and rolling regression approach in a 20 -year window.

Our findings also demonstrate that the increased current account deficit is the main domestic driver of capital sudden stops in Indonesia. However, ensuring a smaller current account deficit is tremendously challenging for the Indonesian economy due to the endless trade war and rising global uncertainty. For instance, the Indonesian economy has experienced a larger current account deficit throughout 2018 due to reciprocal import tariffs between China and the US. The deficit was also caused by the structure of Indonesia's trade balance, which relies excessively on natural resources and raw material exports, implying a lower value-added for Indonesian exports.

Lastly, we found that the contagion effect is mainly driven by the Turkish and South African economies, as their financial interconnectedness with Indonesia is quite close, especially in portfolio investments. On the other hand, Indonesia, Turkey, and South Africa also have similar economic development conditions (Saleem and Ahmed, 2015). This, in turn, induces herding behaviour from foreign capital owners in Indonesia, Turkey, and South Africa and creates a similar path of capital bonanzas and sudden stops.

Our results imply that the episodes of capital bonanzas and sudden stops in Indonesia are driven mainly by domestically uncontrolled factors, i.e., FFR and contagious impacts from financially connected countries. On the other hand, we also found that most domestic factors are problematic; either 
they do not work in the expected direction (e.g., domestic policy rate) or they are difficult to control (i.e., current account deficit). As such, pragmatic policy recommendations are not possible in this area. Therefore, this paper makes some policy suggestions categorised into two clusters: financial regulation and public finance policies.

For financial regulation, two features could enhance the stability and resilience of Indonesia's gross capital inflows in response to the fluctuation of global (or US) interest rates and contagion effects from peer countries. First, the Indonesian government ought to introduce a reverse Tobin tax immediately. Such a policy could effectively control the high volatility of short-run investments (Basri, 2016, 2017). In addition, it could mitigate capital sudden stops due to the contagion effect induced by the herding behaviour of foreign investors. However, this policy is necessary but not sufficient.

The Indonesian economy needs financial sector development, and especially the extensification of financial inclusion. A database developed by Demirgüç-Kunt et al. (2018) shows that, in 2017, financial inclusion in Indonesia reached only $48 \%$ of the population above 15 years old. This number is far below financial inclusion in Malaysia, Thailand, and, obviously, Singapore. The low level of inclusion in Indonesia may reflect fee-based practices in the banking sector; financial banking products may be inaccessible to a portion of the population. Given the limitations of the banking sector, the relevant authorities could support non-banking financial institutions, e.g., peer-to-peer lending and other technological-based financial services. However, the financial sector urgently requires a road map to secure its development, risk, and competitiveness to avoid excessive boom and bust cycles.

Concerning public finance policies, the domestic policy rate has a reverse impact due to external debt conditions and the increased public budget deficit. From another perspective, this is a sign of a more severe problem: fiscal domination. Given this concern, we focus on the policy reform necessary to maintain external debt, especially debt issued by the government, and support a wise public budget. First, we address the debt regulatory framework. One crucial policy must be highlighted in this regard: the Indonesian debt rule. The Indonesian government sets $60 \%$ of GDP as the upper debt-to-GDP ratio (DGR) threshold based on the regulatory framework. While this measure seems politically correct, it is misleading. 
If we trace the historical background of this rule, we will find that it refers to Bohn's condition (BC). BC aims to scrutinise public budget stability, explaining that lower DGR implies a lower public burden; therefore, it could ensure the stability of the public budget by securing safer solvency. However, this rule has faced several criticisms. Although lower debt implies a lower burden, it does not always mean that public debt is sustainable. Taghizadeh-Hesary (2018) has clearly demonstrated that public debt sustainability depends on the supply-demand structure of debt rather than its size (i.e., market-driven debt rule). A decrease in public debt would not ensure the debt's sustainability when demand decreases significantly. We thus recommend reforming the public debt rule, which also captures the market structure of public debt, to ensure debt sustainability.

Second, we highlight procyclical fiscal policy, specifically in Indonesia (see Figure 3), as it is theoretically one of the decisive causes of the growing size of both the public budget deficit and public debt (e.g., Alberola and Montero, 2006; Camous and Gimber, 2018). On the other hand, Kaminsky, Reinhart and Végh (2004) also demonstrated that procyclical economic policy would distort the stability of capital flows. One major cause of procyclical fiscal policy is that the absence of automatic stabilisers (e.g., unemployment insurance) plays a vital role in countercyclical fiscal policy. Moreover, Basri and Raharja (2011) also illustrated that subsidies to the state electricity company and state oil company are Indonesia's main drivers of fiscal procyclicality. We thus suggest a gradual shifting of public budget management in Indonesia. First, it is necessary to gradually reduce the subsidies, especially to oil and gas, and reallocate the budget to intensify Biogas program. This would not only reduce the source of procyclicality but could also reduce high oil imports and the current account deficit. Second, it is essential to begin the step-by-step design and implementation of automatic stabilisers.

\section{Note}

1 Fragile Five Economies (F5Es) are the most fragile economies due to the external shocks during taper tantrum. It includes Indonesia, India, Brazil, Turkey, and South African. 


\section{References}

Alberola, E., Erce, A., \& Serena, J. M. (2016). International reserves and gross capital flows dynamics. Journal of International Money and Finance, 60, 151-171. https://doi.org/10.1016/j.jimonfin.2015.09.003.

Alberola, E., \& Montero, J. M. (2006). Debt Sustainability and Procyclical Fiscal Policies in Latin America. Ssrn. https://doi.org/10.2139/ ssrn.903066.

Ananchotikul, N., \& Zhang, L. (2014). Portfolio Flows, Global Risk Aversion and Asset Prices in Emerging Markets. IMF Working Papers, 14(156), 1. https://doi.org/10.5089/9781498340229.001.

Basri, M. C. (2016). The Fed's Tapering Talk : A Short Statement's Long Impact on Indonesia. Ash Center for Democratic Governance and Innovation, (June), 1-52. Retrieved from: https://ash.harvard.edu/files/ ash/files/taper_tantrum.pdf?m=1466604066

Basri, M. C. (2017). India and Indonesia: Lessons learned from the 2013 taper tantrum. Bulletin of Indonesian Economic Studies, 53(2), 137-160. https://doi.org/10.1080/00074918.2017.1392922.

Basri, M. C., \& Raharja, S. (2011). Mild Crisis, Half Hearted Fiscal Stimulus: Indonesia During the GFC. In T. and F. P. Ito (Ed.), ERIA Research Project Report 2010-01: Assessment on the Impact of Stimulus, Fiscal Transparency and Fiscal Risk (pp. 169-211). Economic Reseach Institute for ASEAN.

Benes, J., Berg, A., Portillo, R., \& Vavra, D. (2015). Modelling sterilized interventions and balance sheet effects of monetary policy in a new keynesian framework. Open Economies Review, 26(1), 232-264. https:// doi.org/10.1007/s11079-014-9320-1.

Bevilaqua, J., \& Nechio, F. (2016). Fed Policy Liftoff and Emerging Markets. FRBSF Economic Letter. Retrieved from http://consensus-inc. com/002001i/knay1537/spec-rep/0718spl-frbsf.pdf.

Bhattarai, S., Chatterjee, A., \& Park, W. Y. (2018). Effects of US Quantitative Easing on Emerging Market Economies. ADBI Working Paper Series. https://doi.org/10.1507/endocrj1954.10.202.

Blanchard, O. J. (2004). Fiscal Dominance and Inflation Targeting: Lessons from Brazil. Ssrn. https://doi.org/10.2139/ssrn.518265.

Calderón, C., \& Kubota, M. (2019). Ride the Wild Surf: An investigation of the drivers of surges in capital inflows. Journal of International 
Money and Finance, 92, 112-136. https://doi.org/10.1016/j. jimonfin.2018.11.007.

Calvo, G. A., Leonardo, L., \& Reinhart, C. M. (1993). Capital inflows and Real Exchange Capital Inflows in Latin America Rate Appreciation. IMF Staff Papers, 40(1), 108-151.

Camous, A., \& Gimber, A. R. (2018). Public debt and fiscal policy traps. Journal of Economic Dynamics and Control, 93, 239-259. https://doi. org/10.1016/j.jedc.2018.02.009.

Cowan, K., Gregorio, J. De, Micco, A., \& Neilson, C. (2008). Financial Diversification, Sudden Stops, and Sudden Starts. Current Account and External Financing, 12(2004), 159-194. Retrieved from http://ideas. repec.org/h/chb/bcchsb/v12c05pp159-194.html.

Dahlhaus, T., \& Vasishtha, G. (2014). The Impact of U.S. Monetary Policy Normalization on Capital Flows to Emerging-Market Economies. Bank of Canada Working Paper, 1-25.

Demirgüç-Kunt, A., Klapper, L., Singer, D., Ansar, S., \& Hess, J. (2018). The Global Findex Database 2017: Measuring Financial Inclusion and the Fintech Revolution. Washington, DC.

Forbes, K. J., \& Warnock, F. E. (2012). Capital flow waves: Surges, stops, flight, and retrenchment. Journal of International Economics, 88(2), 235-251. https://doi.org/10.1016/j.jinteco.2012.03.006.

Friedrich, C., \& Guérin, P. (2020). The dynamics of capital flow episodes. Journal of Money, Credit and Banking, 52(5), 969-1003. https://doi. org/10.1111/jmcb.12614.

Fuertes, A. M., Phylaktis, K., \& Yan, C. (2016). Hot money in bank credit flows to emerging markets during the banking globalization era. Journal of International Money and Finance, 60, 29-52. https://doi.org/10.1016/j. jimonfin.2014.10.002.

Ghosh, A. R., Kim, J., Qureshi, M. S., \& Zalduendo, J. (2014). Surges (IMF Working Paper No. WP/12/22).

Ghosh, A. R., \& Ostry, J. D. (1993). Do Capital Flows Reflect Economic Fundamentals in Developing Countries? (IMF Working Paper Series No. 93/34).

Ghosh, A. R., \& Qureshi, M. S. (2016). Capital Inflow Surges and Consequences. SSRN Electronic Journal, (585). https://doi.org/10.2139/ ssrn.2838069. 
Goeltom, M. S. (2008). Capital flows in Indonesia: challenges and policy responses. BIS Paper, 44, 265-287.

Gujarati, D. N. (2012). Econometrics By Examples (1st Ed.). New York, NY: Palgrave Macmillan.

Gujarati, D. N., \& Porter, D. C. (2009). Basic Econometrics. (A. E. Hilbert, Ed.) (5 ${ }^{\text {th }}$ Ed.) New York, NY: McGraw-Hill/Irwin.

Hannan, S. A. (2015). If the Fed Acts, How Do You React? The Liftoff Effect on Capital Flows (IMF Working Paper No. WP/15/256).

Hannan, S. A. (2018). Revisiting the Determinants of Capital Flows to Emerging Markets - A Survey of the Evolving Literature. IMF Working Papers, 18(214), 1. https://doi.org/10.5089/9781484378281.001.

Indawan, F., Fitriani, S., Permata, M. I., \& Karlina, I. (2013). Capital flows in Indonesia: the behavior, the role, and its optimality uses for the economy. Buletin Ekonomi Moneter Dan Perbankan, 15(3), 23-54. https://doi.org/10.21098/bemp.v15i3.426.

Kaminsky, G. L., Reinhart, C. M., \& Végh, C. A. (2004). When It Rains, It Pours: Procyclical Capital Flows and Macroeconomic Policies (NBER Working Paper Series No. 10780). Cambridge, MA.

Koepke, R., \& Paetzold, S. (2020). Capital Flow Data - A Guide for Empirical Analysis and Real-time Tracking. IMF Working Papers, 20(171). https://doi.org/10.5089/9781513554495.001.

Laeven, L., \& Valencia, F. (2013). Systemic banking crises database. IMF Economic Review, 61(2), 225-270. https://doi.org/10.1057/imfer.2013.12.

Lavigne, R., Sarker, S., \& Vasishtha, G. (2014). Spillover effect of quantitative easing in emerging-market economies. Bank of Canada Review, (Autumn), 23-32.

Nuryakin, C., Yuan, E. Z. W., \& Arsana, I. G. P. (2016). Portfolio flows into Indonesia: Push or pull? Economics and Finance in Indonesia, 62(2), 121. https://doi.org/10.7454/efi.v62i2.550.

Obstfeld, M. (2012). Financial flows, financial crises, and global imbalances. Journal of International Money and Finance, 31(3), 469-480. https://doi. org/10.1016/j.jimonfin.2011.10.003.

Pagliari, M. S., \& Hannan, S. A. (2017). The Volatility of Capital Flows in Emerging Markets: Measures and Determinants. IMF Working Papers, WP/17/41. https://doi.org/10.1300/J383v02n03_03.

Reinhart, C., \& Calvo, G. (1996). Inflows of capital to developing countries in the 1990s. Journal of Economic Perspectives, 10(2), 123-139. 
Reinhart, C. M., \& Reinhart, V. R. (2008). Capital Flow Bonanzas: An Encompassing View of the Past and Present. NBER International Seminar on Macroeconomics, 5(1), 9-62. https://doi.org/10.3386/ w14321.

Saleem, K., \& Ahmed, S. (2015). Intra-market Linkages Among Civets Stock Markets: A New Frontier for Investments. In M. H. Bilgin, H. Danis, E. Demir, C. Keung, M. Lau, E. Business, \& E. S. Conference (Eds.), Innovation, Finance, and the Economy: Proceedings of the 13th Eurasia Business and Economics Society Conference (pp. 181-192). Springer. https://doi.org/10.1007/978-3-319-15880-8.

Taghizadeh-hesary, F. (2018). Fiscal Policy Conditions For Government Budget Stability and Economic Recovery: Comparative Analysis of Japan and Greece (ADBI Working Paper Series No. 851).

Titiheruw, I. S., \& Itje, R. (2008). Managing Capital Flows : The Case of Indonesia (ADB Institute Discussion Paper No. 94). Tokyo, Japan. 


\section{Appendix}

Appendix A. Model Specification Test for Bonanza Episodes

\begin{tabular}{|c|c|c|c|c|c|}
\hline Episode-Identification Criterion & Method & Lag & AIC & SC & HQC \\
\hline \multirow{12}{*}{ Cowan et al. (2008) } & \multirow{4}{*}{$\begin{array}{l}\text { Extreme } \\
\text { values }\end{array}$} & 1 & 1.207006 & 1.717964 & 1.404598 \\
\hline & & 2 & 1.269685 & 1.785347 & 1.468555 \\
\hline & & 3 & 1.23267 & 1.753125 & 1.432812 \\
\hline & & 4 & 1.20257 & 1.727905 & 1.403971 \\
\hline & \multirow{4}{*}{ Logit } & 1 & 1.205767 & 1.716725 & 1.403359 \\
\hline & & 2 & 1.265399 & 1.781061 & 1.46427 \\
\hline & & 3 & 1.241081 & 1.761536 & 1.441223 \\
\hline & & 4 & 1.218498 & 1.743833 & 1.419899 \\
\hline & \multirow{4}{*}{ Probit } & 1 & 1.212341 & 1.723298 & 1.409932 \\
\hline & & 2 & 1.276044 & 1.791706 & 1.474915 \\
\hline & & 3 & 1.238166 & 1.75862 & 1.438308 \\
\hline & & 4 & 1.210647 & 1.735982 & 1.412048 \\
\hline \multirow{12}{*}{$\begin{array}{l}\text { Forbes and Warnock (2012); } \\
\text { Calderón and Kubota (2019) }\end{array}$} & \multirow{4}{*}{$\begin{array}{l}\text { Extreme } \\
\text { values }\end{array}$} & 1 & 1.189791 & 1.700748 & 1.387382 \\
\hline & & 2 & 1.262418 & 1.778081 & 1.461289 \\
\hline & & 3 & 1.231564 & 1.752019 & 1.431706 \\
\hline & & 4 & 1.181598 & 1.706933 & 1.382999 \\
\hline & \multirow{4}{*}{ Logit } & 1 & 1.183389 & 1.694347 & 1.380981 \\
\hline & & 2 & 1.273201 & 1.788864 & 1.472072 \\
\hline & & 3 & 1.220842 & 1.741296 & 1.420983 \\
\hline & & 4 & 1.197346 & 1.722681 & 1.398747 \\
\hline & \multirow{4}{*}{ Probit } & 1 & 1.190586 & 1.701544 & 1.388177 \\
\hline & & 2 & 1.277918 & 1.79358 & 1.476788 \\
\hline & & 3 & 1.228423 & 1.748877 & 1.428564 \\
\hline & & 4 & 1.189377 & 1.714711 & 1.390778 \\
\hline
\end{tabular}


Appendix B. Model Specification Test for Sudden Stop Episodes

\begin{tabular}{cccccc}
\hline Episode-Identification Criterion & Method & Lag & AIC & SC & HQC \\
\hline & & 1 & 1.45125 & 1.962208 & 1.648842 \\
& Extreme & 2 & 1.263532 & 1.779194 & 1.462402 \\
& values & $\mathbf{3}$ & $\mathbf{1 . 2 2 8 7 7 1}$ & $\mathbf{1 . 7 4 9 2 2 6}$ & $\mathbf{1 . 4 2 8 9 1 3}$ \\
\cline { 2 - 6 } & & 4 & 1.318478 & 1.843813 & 1.519879 \\
\hline Cowan et al. (2008); & & 1 & 1.396045 & 1.907002 & 1.593636 \\
Forbes and Warnock (2012); & Logit & 2 & 1.252917 & 1.76858 & 1.451788 \\
Calderón and Kubota (2019) & & $\mathbf{3}$ & $\mathbf{1 . 2 4 9 1 1 9}$ & $\mathbf{1 . 7 6 9 5 7 4}$ & $\mathbf{1 . 4 4 9 2 6 1}$ \\
\cline { 2 - 6 } & & 4 & 1.313644 & 1.838979 & 1.515045 \\
\cline { 2 - 6 } & & 1 & 1.411029 & 1.921986 & 1.60862 \\
& & 2 & 1.254634 & 1.770297 & 1.453505 \\
\hline & & $\mathbf{3}$ & $\mathbf{1 . 2 3 9 0 3 3}$ & $\mathbf{1 . 7 5 9 4 8 8}$ & $\mathbf{1 . 4 3 9 1 7 5}$ \\
\hline
\end{tabular}

